\title{
Being a woman, mother to a child with cerebral palsy*
}

\author{
Ser mulher mãe de uma criança portadora de paralisia cerebral \\ Ser mujer madre de un niño portador de parálisis cerebral
Viviane Marten Milbrath', Diana Cecagno², Deisi Cardoso Soares ${ }^{3}$, Simone Coelho Amestoy ${ }^{1}$, Hedi Crecencia Heckler de Siqueira ${ }^{4}$

\begin{abstract}
Objective: To get to know the adaptation process experienced by a woman, motivated by the birth of a child with cerebral palsy. Methods: The investigation was performed with a descriptive, exploratory methodology, focusing on the qualitative approach. Six women, mothers of children with brain palsy, participated in the study. Data collection happened in an institution that delivers care to children with special needs, located in a town of the state of Rio Grande do Sul, Brazil. Results: data analysis revealed that the woman abdicates from her social, professional and even personal life to take better care of her child. Besides, these mothers were shown to need psychosocioeconomic support from their families and the people who surround them, in both the process of initial adaptation and overcoming and the whole period of care for the child. Conclusion: The woman assumes and experiences the responsibility of taking care of the child with special needs.
\end{abstract}

Descriptores: Disabled children; Cerebral palsy; Women; Mothers/psychology

\section{RESUMO}

Objetivo: Conhecer o processo de adaptação vivenciado pela mulher, motivado pelo nascimento de um filho portador de paralisia cerebral. Métodos: A investigação contemplou uma metodologia descritiva, exploratória à luz de uma abordagem qualitativa. Participaram do estudo seis mulheres, mães de crianças portadoras de paralisia cerebral. A coleta dos dados foi realizada numa instituição que atende crianças portadoras de necessidades especiais, localizada em um município do Rio Grande do Sul. Resultados: A análise dos dados revelou abdicação, pela mulher, da vida social, profissional e, até mesmo pessoal, em prol do cuidado de seu filho. Além disso, essas mães demonstraram necessitar de apoio psico-sócio-econômico familiar e das pessoas que as cercam, tanto durante o processo de adaptação e superação vivencial inicial, quanto durante todo o período do cuidado à criança. Conclusão: A mulher assume e vivencia a responsabilidade pelo cuidado do filho portador de necessidades especiais.

Descritores: Crianças portadoras de deficiência; Paralisia cerebral; Mulheres; Mães/psicologia

\section{RESUMEN}

Objetivo: Conocer el proceso de adaptación vivenciado por la mujer, motivado por el nacimiento de un hijo portador de parálisis cerebral. Métodos: La investigación contempló una metodología descriptiva, exploratoria a la luz de un abordaje cualitativo. Participaron en el estudio seis mujeres, madres de niños portadores de parálisis cerebral. La recolección de los datos se llevó a cabo en una institución que atiende a niños portadores de necesidades especiales, localizada en un municipio de Río Grande del Sur. Resultados: El análisis de los datos reveló abdicación, de la mujer, de su vida social, profesional y, hasta personal, en pro del cuidado de su hijo. Aparte de ello, las madres demostraron que necesitan de apoyo psico-socio-económico familiar y de las personas que las rodean, tanto durante el proceso de adaptación y superación de las vivencias iniciales, como durante todo el período del cuidado al niño. Conclusión: La mujer asume y vivencia la responsabilidad del cuidado del hijo portador de necesidades especiales.

Descriptores: Niños con discapacidad; Parálisis cerebral; Mujeres; Madres/psicología

\footnotetext{
* Study performed at Centro de Reabilitação de Necessidades Especiais in Pelotas (RS), Brazil.

${ }^{1}$ Graduate nursing student by the Fundação Universidade Federal do Rio Grande - FURG - Rio Grande (RS), Brazil; Member of the Núcleo de Estudos e Pesquisa: Gerenciamento Ecossistêmico em Enfermagem/Saúde ( GEES)

${ }^{2}$ Master in Nursing by the Fundação Universidade Federal do Rio Grande - FURG - Rio Grande (RS), Brazili; Vice-Leader and Member of the Núcleo de Pesquisa GEES

${ }^{3}$ Master in Nursing by the Fundação Universidade Federal do Rio Grande - FURG - Rio Grande (RS), Brazil; Member of the Núcleo de Pesquisa GEES ${ }^{4}$ MD, Hospital Administrator, Professor of the Graduate Nursing Program at the Fundação Universidade Federal do Rio Grande - FURG - Rio Grande (RS), Brazil; Leading Member of the Núcleo de Pesquisa GEES
} 


\section{INTRODUCTION}

Women carry the duty of becoming mother to a child within certain "standards" defined by society. Successful pregnancy and birth can be considered a victory, in which the woman has the feeling of confirmation of her power/competence in the task of procreating ${ }^{(1)}$. However, the birth of a child with special needs shatters this feeling of capacity/reliability, causing a slow and deep narcissist wound that is very difficult to heal ${ }^{(2)}$. This makes the family face an extremely delicate situation, in which ambiguous feelings arise in the face of this new being ${ }^{(1-3)}$.

Each individual in the family core experiences the process of adaptation to the child with special needs in a unique way since, despite receiving similar stimuli from the environment, each will have his/her own coping mechanism ${ }^{(4)}$. According to Roy's Adaptation Model, each human being experiences, in a specific way, the adaptation processes ( $\mathrm{s}$ ) he is exposed to, since this person is seen as an adaptive system, constantly responding to internal and external environmental stimuli ${ }^{(4-5)}$. Therefore, the adaptive responses of the adaptation process make them re-find the lost balance, accepting the situation, in this case cerebral palsy, as a part of their own, their child's and their family's life ${ }^{(5)}$.

The family, faced with this process of adaptation, often needs to rethink its structure and organization as a group, because the care for a child with special needs demands the constant presence of a caregiver, usually the mother. However, even considering that the womanmother is the caregiving figure, she will need a supporting social network to obtain efficient adaptive responses when experiencing such a process.

The supporting social network can also be considered a system composed of many people with specific functions, who offer emotional, financial and educational support, besides sharing responsibilities ${ }^{(6-7)}$, since they exert a specific influence on maternal coping mechanisms.

The aforementioned problem generated the following questions: How does the woman-mother of a child with cerebral palsy experiences the process of adaptation? Does she need and accept to use supporting networks?

Based on what was exposed, the objective of this study was to get to know the process of adaptation experienced by a woman, motivated by the birth of a child with cerebral palsy.

\section{METHODS}

A descriptive, exploratory methodology was used, within a qualitative approach. It is qualitative because it seeks to incorporate the meaning and intention of the actions of women-mothers of children with cerebral palsy, discovering the relations and social structures capable of providing support in the process of adaptation. Therefore, it also works with meanings, reasons, aspirations, beliefs, values and attitudes, in constant transformation ${ }^{(8)}$.

The research project was approved by the Review Board of the Federal University of Pelotas, under number 045/06. After the institution's formal acceptance, the subjects were contacted and invited to participate in the study. All of them accepted and were willing to collaborate with the study. Next, an interview was scheduled. When the proposal was made, the participants were required to sign two copies of the term of consent, one for the participant and the other for the researcher in charge. The legal and ethical aspects involved and the freedom to cease participation at any time without personal harm were emphasized. Also, anonymity and confidentiality were guaranteed. The collected data remain under the responsibility of the researcher in charge.

The subjects were chosen randomly among womenmothers of children with cerebral palsy attending an institution that delivers care to children with special needs, in a city in Rio Grande do Sul. All of the invited mothers accepted to participate in the research. The number of subjects was limited according to data saturation ${ }^{(8)}$, i.e. the interviews continued while new data were being added, and were considered finished when the data became repetitive. The final number of women-mothers participating in the study was six, identified with the pseudonyms mother \#1, mother \#2, and so on, up to mother \#6.

Data were collected from July to September, 2006, through a semi-structured interview, based on the following questions: How did you experience the birth of your child with cerebral palsy? How could you perform the adaptations in your life to care for your child? Did you need to use supporting networks to care for your child? How, and which? All subjects allowed the interviews to be recorded. Thematic analysis was chosen to analyze the collected data, consisting in three stages: pre-analysis, data exploration, treatment of the results obtained and interpretation ${ }^{(8)}$. In pre-analysis, the collected data were fully transcribed. Afterwards, floating readings and re-readings were performed, aimed at exhaustive contact with the collected information.

Next, the data were organized through individual visualization of each interview, highlighting the relevant aspects. After this stage, the interviewees' statements were mapped and the main points of each statement were signaled in order to facilitate the visualization of the material as a whole.

In the stage of data exploration, every significant fragment in the material was highlighted, i.e. words, phrases, paragraphs with the same thematic content, identifying the 
units of registry and performing the necessary cuts. New readings were performed, aiming at apprehending the manifested and/or occult meaning of the observations and information contained in the reports, leading to new reflections, with a view to grouping the data and establishing the categories.

\section{RESULTS}

Regarding the proposed theme, from data analysis to interviews, two themes emerged: Experiencing being a woman-mother of a child with cerebral palsy and Supporting networks necessary to the woman-mother of a child with special needs.

\section{Experiencing being a woman-mother of a child with cerebral palsy}

The process of adaptation and overcoming experienced by the woman, motivated by the birth of a child with cerebral palsy, was described as a unique event, with deep and complex individual and family repercussions.

Well, the changes were all, in general, like this, our life changed completely all of a sudden, because it was only me and my husband, and suddenly there came a son, and with a handicap (mother \#1).

I think that, when I became aware of the care he needed [...], my entire life changed (mother \#2).

In some cases, the perception of the need for special care, added to the willingness to provide adequate stimuli to potentialize the child's development to its full extent, can make the mothers leave the job market, resulting in exclusive dedication to their child, a fact that was verified in the following statements:

I had to stop working to take care of him [...] also, I was afraid that he would have something while away from me (mother \#1).

I quit my job, because I couldn't afford to pay someone to take care of him, taking him everywhere (therapies, you know) (mother \#2).

I had to quit my job to take care of him, because there was nobody who could take care of him, especially because of the seizures (mother \#3).

I was forced to stop working, with the registry and all, there was nobody to take care of him, [...] my husband says I don't trust anyone to take care of him, hey, but I'm afraid (mother \#6).

Therefore, the process experienced by the woman, when becoming mother to a child with cerebral palsy, alters the mother-subject' homeostasis, and also that of the family group.

Supporting networks necessary to the womanmother of a child with special needs

The mothers' reports about the process of adaptation to the child with cerebral palsy showed that they used supporting networks as a mechanism to facilitate their adaptive responses, both in the initial process of living adaptation and during the whole period of care for the child.

Our family had to get much closer, and we needed a lot of help, and we helped each other, my husband and me, and also the grandparents (our parents), godparents, the whole family together (mother \#1).

$I$ and my husband and my parents help a lot (mother \#3).

$I$ had the support of my husband at home, and after that, the whole family that belped me, but they keep asking me why there has to be someone different in the family, and I don't even know how to answer that, so what should I say? (mother \#4).

It can be observed in the mother's reports that they used the family as their main supporting network, with emphasis on the husband/partner and their own parents. However, it was revealed that the family brings demands for them because of the birth of a child with special needs.

[...] all right, they belp me a lot, I have nothing to complain about, but these questions, man, it seems like I wanted my son to be sick (mother \#4).

Regarding the child's father, out of the six participants of the study, five reported receiving support. However, one mother stated that her husband, after receiving the news of cerebral palsy and its consequences, abandoned her and her child:

My husband left me when he knew about the problem. He couldn't take the pressure and the only comfort I had at this time was from my family (mother \#5).

\section{DISCUSSION}

Through the mothers' statements, the coping mechanisms could be understood which each "womanmother", in her own individuality, had to use to be able to overcome the moments of uncertainty, grief and concerns, in order to correspond to the care needs when she became the mother of a newborn with special needs, as a consequence of the cerebral palsy diagnosis.

The family, as a whole, was extremely influenced by the impact of becoming a family of a child with cerebral palsy, which triggered a (re)organization of its structure and (re)definition of roles. According to the social actors of the study, the families experienced an internal unity, especially considering the extended family (grandmother, grandfather, uncle, aunt), because of the financial, emotional and affective support to aid in care for the child. 
The experience of having a child, by itself, introduces great changes in the life of a couple. However, when they face an unexpected fact that demands a complete change in their way of life, it strays away completely from the planned/expected plans and expectations. Therefore, when the participant mother \#1 says [...] "and suddenly there comes a child with a handicap", it confirms the fact that the family is only prepared for the birth of a "normal" child, i.e. the handicap comes as something extremely unexpected and impacting, causing fear and anxiety in view of the unknown. When the parents receive the news of the diagnosis, they experience the loss of an idealized child. This fact is capable of jeopardizing the whole intra-family homeostasis, since the imaginary situation enters and commands the unconscious minds of these parents ${ }^{(1-3)}$.

"The adaptation to the situation of having a child with cerebral palsy does not happen magically. It is a complicated and permanent process" (9). From the diagnosis, the families experience a radical change in their daily routine, and, to take care of the child, the family core needs to be (re)structured, considering that playing the role of mother and father of a child with special needs is something new that needs to be learned ${ }^{(10)}$. This shows that each person needs to adapt continually to the situations that arise, in order to attain the adaptive responses, i.e. to maintain their integrity ${ }^{(4)}$.

As for the child's future, the family abdicates from several plans. Daily family life starts to be (re)designed to benefit the newborn. The family undergoes a process of adaptation, using the coping mechanisms in order to seek adaptive responses that are capable of developing an adequate environment for the inclusion of this child( ${ }^{(4)}$.

When participant mother \#2 says [...] "I became aware of the care be needed [...], all my life changed", she confirms that the process of perception is slow and that, at the moment they become aware of it, many changes happen in the mother's life, seeking to benefit the child who needs special care.

The statements of mothers \#1, \#2, \#3 and \#6 show that they left their jobs, interrupted part of their social life and dedicated themselves exclusively to care for their child. The woman's act of abdicating from her professional life to dedicate herself exclusively to being a mother alters her routine and influences the family as a whole because, when quitting her job, besides lowering the family income, she starts to depend financially on others. It is worth noting that all study participantswho worked outside the house quit their jobs, and only kept their job if they worked in their family's business.

Therefore, the mother was identified as the first and foremost caregiver of the child with special needs. However, the participants mentioned that they could count on supporting networks to cope with and overcome the difficulties they faced. Among these networks, the family is especially noted as the main source of support and adaptation.

By observing this perspective, it is evident that the family represents a link capable of redefining its structure and organization, and is the constructive support in a supporting network to the mother-woman who assumed the function of caregiver, since her situation requires the comprehension of all family members and people they have relations with.

There are several people who should offer support to the mother and the family as a whole. Among them, the grandparents, uncles, aunts, cousins, friends, partners, neighbors, teachers and healthcare professionals are worth of note ${ }^{(6-7)}$. The people comprising the social support network and the functions they perform in the family change according to the social, cultural, financial and historical context, and the stage of development of each individual and family, considered as a group ${ }^{(11)}$.

This supporting network is considered indispensable by the families. Besides, some studies have proven that the parents comprise the family as the first supporting network, especially focusing on the grandparents ${ }^{(7)}$. According to another earlier study ${ }^{(6)}$, the mothers mentioned the support of their husband/partner as the main source of support they received, followed by the support of their own mother, leaving the group of friends and other family members in a third, but also important, place. These same members were well-regarded in the present study.

The analysis of the statements confirms that each family faces deficiency differently. Some mothers experienced closeness with their families because of the need for support felt by the child's parents at the time of the diagnosis and when providing care. However, mother \#4 mentioned receiving support from her family, but she also suffers, at the same time, questionings about "why" her family has someone with special needs. This situation causes an ambiguous feeling in the mother, because she needs help but, at the same time, she feels "guilty".

The questioning, by family members, about the reasons for the existence of a handicapped member in their family core can be a sign of prejudice towards him or her since, subjectively, they convey the idea of "punishment" or a fact that "hurts" the image of the perfect family, with physically "perfect" members. This is a cultural issue that has infected society since ancient Greece, where the only role of the woman was to give birth to warriors, i.e. sons that were physically strong and perfect ${ }^{(1-12)}$.

Regarding the father figure, it is interesting to note that he is particularly important, because the attitudes of the parents usually influence the other members of the family, especially the mother ${ }^{(6-11)}$. The (re)organization of the family becomes easier when the couple - the child's 
parents - is mutually supportive ${ }^{(13)}$. The strong emphasis manifested by the study participants (mother \#1, mother \#2 and mother \#4) on the participation of the father in the support showed how much he is necessary to help in the (re)organization of the family.

Mother \#5 described that her husband, after receiving the news about the cerebral palsy and its consequences, abandoned her and her child. As a result of this experience, she had to cope with the dissolution of her relationship with her husband, along with the process of adaptation to cerebral palsy. Fathers show more difficulty than mothers in dealing with a child with special needs, especially those with a cerebral palsy diagnosis, who present chronic needs $s^{(13)}$.

The woman, differently from the man, is considered a caregiver per excellence ${ }^{(14)}$ and, as such, is the one who usually takes the responsibility of becoming the main caregiver. However, the reality of being the main caregiver demands nearly exclusive attention and, therefore, abdication from other social commitments.

\section{FINAL CONSIDERATIONS}

The study allowed the authors to understand that the mother-woman assumes and experiences the responsibility of caring for children with special needs. When adopting this complex attitude, she can, perhaps unconsciously, demand from herself the obligation and responsibility of caring for the person she was capable of bearing, and thus consider the fact of caring for a child as an intrinsically determined necessity. This process experienced by the mother, associated to the female vocation for caring, can

\section{REFERENCES}

1. Ievorlino SA. Estudo das percepções, sentimentos e concepções para entender o luto de familiares de portadores da síndrome de Down da cidade de Sobral - Ceará [tese]. São Paulo: Faculdade de Saúde Pública da Universidade de São Paulo; 2005.

2. Soifer R. Psicologia da gravidez, parto e puerpério. 6a ed. Porto Alegre: Artes Médicas; 1992.

3. Leal EN. A criança com Síndrome de Down: expectativa da família quanto ao processo de inclusão escolar [dissertação]. Ribeirão Preto: Faculdade de Filosofia Ciências e Letras de Ribeirão Preto da Universidade de São Paulo; 2006.

4. Gralbreath JG. Sister Callista Roy. In: George JB. Teorias de enfermagem: fundamentos para a prática profissional. Porto Alegre: Artes Médicas; 1993. p.206-26.

5. Brandalize DL, Zagonel IPS. Um marco conceitual para o cuidado familiar da criança com cardiopatia congênita à luz da teoria de Roy. Cogitare Enferm. 2006; 11(3):264-70.

6. Dessen MA, Braz MP. Rede social de apoio durante transições familiares decorrentes do nascimento de filhos. Psicol Teor Pesqui. 2000; 16(3):221-31.

7. Vasconcelos MGL, Leite AM, Scochi CGS. Significados be considered responsible for the fact that the mother is the main caregiver, many times abdicating from her social, professional and personal life, since the role of "mother" becomes her priority.

It was seen that questionings and guilt were interspersed with an ambiguity of feelings, including fears, anxieties, dedication and love for the child, directly influencing the process of adaptation experienced by the woman who cares for a child with cerebral palsy. However, it was evident that, although the woman-mother is considered the direct caregiver of the child with special needs, she needed to use social support networks that would be able to help her fulfill her own needs, as well as the child's. In this social support network, according to the subjects, the family was noted as the main unit, serving as the link to support and provide the necessary support, with solidarity.

In this study, a fact that attracted attention was that no mother mentioned the healthcare units as the supporting network in the interviews, nor considered healthcare professionals necessary and part of the supporting network of the mother-child dyad. This absence can mean distancing between the healthcare services and the families of children with cerebral palsy. However, their presence would probably aid in the process of adaptation and coping mechanisms capable of providing adaptive responses. The nurse is especially included in this context, since she has an integralizing view. Based on Roy's theory, she can aim at adaptive responses as part of her working process, minimize inefficient responses and, therefore, obtain improvements in the care delivered to the motherchild dyad and, also, strengthen the affective bond between both, attaining a better quality of life. atribuídos à vivência materna como acompanhante do recémnascido pré-termo e de baixo peso. Rev Bras Saude Matern Infant. 2006; 6(1):47-57.

8. Minayo MCS. O desafio do conhecimento: pesquisa qualitativa em saúde. 10a ed. São Paulo: Hucitec; 2007.

9. Geralis E, organizadora. Crianças com paralisia cerebral. Guia para pais e educadores. Porto Alegre: Artmed; 2007.

10. Lemes LC, Barbosa MAM. Comunicando à mãe o nascimento do filho com deficiência. Acta Paul Enferm. 2007; 20(4):441-5.

11. Silva NLP, Dessen MA. Deficiência mental e família: implicações para o desenvolvimento da criança. Psicol Teor Pesqui. 2001; 17(2):133-41.

12. Aymard A. O oriente e a Grécia antiga. In: Crouzet M. História geral das civilizações. $3^{\mathrm{a}}$ ed. Tradução Pedro Moayir Campos. São Paulo: Difusão Européia do Livro;1960. (Série: História Geral das Civilizações,1).

13. Araújo RCF. A síndrome de Down numa perspectiva da paternagem [dissertação]. Viçosa (MG): Universidade Federal de Viçosa. Faculdade de Economia Doméstica; 2002.

14. Waldow VR. O cuidado humano: o resgate necessário. Porto Alegre: Editora Sagra Luzzatto; 1998. 